\begin{tabular}{|l|l|l||}
\hline \multicolumn{2}{|c|}{ PublisherInfo } \\
\hline \hline PublisherName & $:$ & BioMed Central \\
\hline \hline PublisherLocation & $:$ & London \\
\hline \hline PublisherImprintName & $:$ & BioMed Central \\
\hline \hline
\end{tabular}

\title{
Human endogenous retroviruses
}

\begin{tabular}{|l|l|l||}
\hline \multicolumn{2}{|c|}{ ArticleInfo } \\
\hline \hline ArticleID & $:$ & 4253 \\
\hline \hline ArticleDOI & $:$ & $10.1186 /$ gb-spotlight-20011115-02 \\
\hline \hline ArticleCitationID & $:$ & spotlight-20011115-02 \\
\hline \hline ArticleSequenceNumber & $:$ & 324 \\
\hline \hline ArticleCategory & $:$ & Research news \\
\hline ArticleFirstPage & $:$ & 1 \\
\hline \hline ArticleLastPage & $:$ & 2 \\
\hline \hline & $:$ & RegistrationDate : 2001-11-15 \\
ArticleHistory & $:$ & OnlineDate $:$ 2001-11-15 \\
\hline \hline ArticleCopyright & $:$ & BioMed Central Ltd2001 \\
\hline \hline ArticleGrants & $:$ & \\
\hline \hline ArticleContext & $:$ & 130592211 \\
\hline \hline
\end{tabular}




\section{Jonathan B Weitzman}

Email: jonathanweitzman@hotmail.com

Our genomes are scattered with large numbers of human endogenous retroviruses (HERVs), presumed left-overs from early retroviral infections. In the Advanced Online Publication of Nature Genetics, Jennifer Hughes and John Coffin, from the Tufts University School of Medicine in Boston, describe 23 new members of the HERV-K (HML-2) group of sequences and examine their rearrangement during evolution (DOI: 10.1038/ng775). They analysed the 5 ' and 3' LTR sequences of 35 provirus HERV-K elements and found evidence for inter-element recombination events in six elements (16\%). HERV recombination may have influenced genomic rearrangements and the evolution of the human genome, for example via insertion/deletion events in the class I major histocompatibility region.

\section{References}

1. Many human endogenous retrovirus K (HERV-K) proviruses are unique to humans.

2. Nature Genetics, [http://genetics.nature.com]

3. Tufts University School of Medicine , [http://www.tufts.edu/med/]

4. Coevolution of PERB11 (MIC) and HLA class I genes with HERV-16 and retroelements by extended genomic duplication. 